\title{
Diversity of small mammals synusias of the open forest sites of the Beskydy and Jeseníky Mts.
}

\author{
L. Čepelka ${ }^{*}$, J. Suchomel ${ }^{1}$, L. Purchart ${ }^{1}$, M. Heroldová ${ }^{2}$
}

${ }^{1}$ Department of Forest Ecology, Faculty of Forestry and Wood Technology, Mendel University of Agriculture and Forestry in Brno, Zemédèlská 3, 61300 Brno, Czech Republic, *e-mail: cecna@seznam.cz

${ }^{2}$ Institute of Vertebrate Biology, AV ČR, Kvétná 8, 60365 Brno, Czech Republic

\begin{abstract}
L., Suchomel J., Purchart L., Heroldová M. 2012: Diversity of small mammals synusias of the open forest sites of the Beskydy and Jeseníky Mts. - Beskydy, 5 (2): $121-134$

Small mammal communities were studies in tree plantations in 2007-2011. The monitoring was conducted at 18 plots in the Jeseníky Mts. and 18 plots in the Beskydy Mts. using snap traps placed in lines. A total of 588 individuals of 10 species were captured in the Jeseníky Mts. and 577 individuals of 13 species in the Beskydy Mts. The Beskydy lot encompassed 5 insectivorous species and 8 rodent species, 4 of them eudominant (Apodemus flavicollis, $\mathrm{D}=43.33 \%$; Clethrionomys glareolus, $\mathrm{D}=21.49 \%$; Microtus agrestis, $\mathrm{D}=18.54 \%$; and Sorex araneus, $\mathrm{D}=10.05 \%$ ), one subdominant (Apodemus sylvaticus, $\mathrm{D}=2.77 \%$ ), two recedent (Microtus arvalis, $\mathrm{D}=1.39 \%$; Muscardinus avellanarius, $\mathrm{D}=1.04 \%$ ) and six sub-recedent (Microtus subterraneus and Sorex minutus: $\mathrm{D}=0.35 \%$ and Apodemus agrarius, Neomys anomalus, Sorex alpinus and Talpa europea: $\mathrm{D}=0.17 \%)$. The occurrence of 3 insectivorous species and 7 rodent species was confirmed in the Jeseníky Mts. Four species were eudominant (A. flavicollis, D=30.1\%; Clethrionomys glareolus, $\mathrm{D}=27.04 \%$; Microtus agrestis, $\mathrm{D}=24.49 \%$; and $\mathrm{S}$. araneus, $\mathrm{D}=12.59 \%)$, one species subdominant (Microtus arvalis; $\mathrm{D}=3.57 \%$ ), five species sub-recedent (A. sylvaticus, $\mathrm{D}=0.68 \%$; Crocidura suaveolens and Microtus subterraneus: $\mathrm{D}=0.34 \%$, Muscardinus avellanarius and S. minutus: $\mathrm{D}=0.17 \%)$. According to the employed indexes, the total biodiversity was slightly higher in the Jeseníky Mts. ( $\mathrm{H}=1.53 ; \mathrm{d}=0.76$; $\mathrm{E}=0.66)$ than in the Beskydy Mts. $(\mathrm{H}=1.52 ; \mathrm{d}=0.72 ; \mathrm{E}=0.59)$. The structure of the small mammal communities was strongly affected by the herb layer composition.
\end{abstract}

Keywords: small mammals, Rodentia, Soricomorpha, diversity, forest ecosystems, Jeseníky Mts, Beskydy Mts.

\section{Introduction}

The research of small mammals in the Beskydy and Jeseníky Mts. has varying intensity. This particularly refers to studies of small mammal communities in production forests, including their impact on forest stands. While the Jeseníky Mts. have been subject to research in the recent years, studies in the Moravskoslezské Beskydy Mts. has been systematically conducted since the 1980s, when studies of the Smrk ecosystem heavily affected by air pollution were launched (e.g. Heroldová and Zejda 1995, Čapek et al. 1998). This research was extended to include the area of a valuable, trans-regional biocentre Kněhyně - Čertův Mlýn in 1997-2000 (Bryja et al. 1999, 2001a, 2001b). After several years, the research was renewed in 2005 with the objective to obtain more information on changes in the small mammal community and its impact on natural forest regeneration as well as on artificial plantations (Suchomel et al. 2007). Initially, the study focused only on the original study sites in the area of Kněhyně. Starting with 2007 the research widened to include the complex of Smrk under a specialized project focusing on small mammal impact on tree plantations. 
Apart from a single environmental study of sites affected by air pollution (Nesvadbová, Gaisler 2000), only faunisic data on the occurrence of individual small mammal species are available from the Jeseníky Mts (Anděra and Beneš 2001, 2002; Anděra 2000, 2011) as well as a one-off monitoring of browsing damage to trees summarized by Kamler et al. (2010, 2011). Preliminary evaluations of habitat preferences of selected small mammal species in a nonforest environment (Suchomel et al. 2009) and the impact of voles (Arvicolinae) on beech (Fagus sylvatica) plantations (Suchomel et al. 2011) were conducted in the area only recently. Other available studies are much older and either complement more complex studies of mammals (e.g. Remeš 1927; Kratochvíl and Grulich 1949, 1950; Beneš 1974, 1986) or focus on sites attractive from the nature-protection perspective, such as the so-called Velká kotlina (e.g. Kratochvíl 1955; Zapletal 1957) and not on areas subject to forest management.

From 2007 to 2011, research of the impact of small mammals on tree plantations under the project NAZV: "Small Mammals, a significant factor in the forest regeneration process" took place in both mountain ranges. The aim of the presented paper is to summarize data and provide information on the number of species, the community structure and the diversity of open habitat small mammals in the given areas and to compare the monitored communities.

\section{Material and Methods}

18 plots of tree plantations in each mountain range (a total of 36) were selected in the areas of the Jeseníky and Beskydy Mts. (Czech Republic). The experimental plots were delimited at various altitudes, with various exposures and covers (70-100\%) and varying character of the herb layer (for details see Tab. 1-4). The monitored tree species in the Jeseníky Mts. was purely beech (Fagus sylvatica), while in the Beskydy Mts. the sycamore maple (Acer pseudoplatanus) on plot 16 and the silver fir (Abies alba) on plots 5 and 18 were monitored as well, see Tab. 3 and 4. The plantation age at the first year of monitoring (2007) was 5-7 years. The area of the plots ranged between 0.2-0.5 ha. Small mammals were captured at the plots once in every year in the autumn, i.e. five times in total (2007-2011). Trappings were conducted under a project studying the gnawing impact of small mammals on forest regeneration and for its purposes the once-a-year sampling was sufficient. The trapping was done using snap traps placed

Tab. 1: Basic geographical characteristics of the experimental plots in the Jeseníky Mts.

\begin{tabular}{|c|c|c|c|c|}
\hline Site & GPS & Altitude & FVB & Exposure \\
\hline 1 & $\mathrm{~N} 50^{\circ} 12^{\prime} 41^{\prime \prime} \mathrm{E} 017^{\circ} 19^{\prime} 34^{\prime \prime}$ & 730 & 5 & 0 \\
\hline 2 & N501 $14^{\prime} 06^{\prime \prime} \mathrm{E} 017^{\circ} 19^{\prime} 09^{\prime \prime}$ & 690 & 5 & SW \\
\hline 3 & $\mathrm{~N} 50^{\circ} 14^{\prime} 00^{\prime \prime} \mathrm{E} 017^{\circ} 19^{\prime} 22^{\prime \prime}$ & 710 & 5 & SW \\
\hline 4 & $\mathrm{~N} 50^{\circ} 09^{\prime} 28^{\prime \prime} \mathrm{E} 017^{\circ} 15^{\prime} 02^{\prime \prime}$ & 1010 & 7 & 0 \\
\hline 5 & $\mathrm{~N} 50^{\circ} 10^{\prime} 12^{\prime \prime} \mathrm{E} 017^{\circ} 14^{\prime} 14^{\prime \prime}$ & 910 & 6 & $\mathrm{~W}$ \\
\hline 6 & 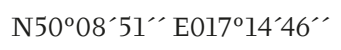 & 1035 & 7 & $\mathrm{NE}$ \\
\hline 7 & $\mathrm{~N} 50^{\circ} 12^{\prime} 58^{\prime \prime} \mathrm{E} 017^{\circ} 19^{\prime} 45^{\prime \prime}$ & 755 & 5 & 0 \\
\hline 8 & 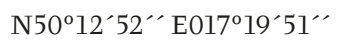 & 745 & 5 & 0 \\
\hline 9 & $\mathrm{~N} 50^{\circ} 14^{\prime} 03^{\prime \prime} \mathrm{E} 017^{\circ} 19^{\prime} 04^{\prime \prime}$ & 720 & 5 & $\mathrm{NE}$ \\
\hline 10 & $\mathrm{~N} 50^{\circ} 12^{\prime} 11^{\prime \prime} \mathrm{E} 017^{\circ} 20^{\prime} 29^{\prime \prime}$ & 705 & 6 & E-SE \\
\hline 11 & $\mathrm{~N} 50^{\circ} 12^{\prime} 54^{\prime \prime} \mathrm{E} 017^{\circ} 18^{\prime} 13^{\prime \prime}$ & 770 & 6 & NW \\
\hline 12 & $\mathrm{~N} 50^{\circ} 12^{\prime} 53^{\prime \prime} \mathrm{E} 017^{\circ} 18^{\prime} 25^{\prime \prime}$ & 790 & 6 & NW \\
\hline 13 & $\mathrm{~N} 50^{\circ} 12^{\prime} 30^{\prime \prime} \mathrm{E} 017^{\circ} 18^{\prime} 40^{\prime \prime}$ & 785 & 6 & SE \\
\hline 14 & $\mathrm{~N} 50^{\circ} 12^{\prime} 36^{\prime \prime} \mathrm{E} 017^{\circ} 18^{\prime} 35^{\prime \prime}$ & 820 & 6 & SE \\
\hline 15 & $\mathrm{~N} 50^{\circ} 06^{\prime} 50^{\prime \prime} \mathrm{E} 017^{\circ} 11^{\prime} 21^{\prime \prime}$ & 1070 & 7 & NW \\
\hline 16 & 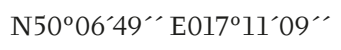 & 1065 & $7-8$ & 0 \\
\hline 17 & $\mathrm{~N} 50^{\circ} 07^{\prime} 09^{\prime \prime} \mathrm{E} 017^{\circ} 11^{\prime} 04^{\prime \prime}$ & 1040 & 7 & SW \\
\hline 18 & $\mathrm{~N} 50^{\circ} 07^{\prime} 03^{\prime \prime} \mathrm{E} 017^{\circ} 12^{\prime} 41^{\prime \prime}$ & 1085 & 7 & $\mathrm{E}$ \\
\hline
\end{tabular}

(FVB - Forest vegetation belt) 
in lines (one line of 34 traps per plot). The traps were baited with a wick fried in flour and oil and in the course of a trapping event the bait was repeatedly smeared with peanut butter. The traps were exposed for three consequent nights. The monitored communities were subject to evaluation of basic environmental characteristics, such as number of species, their abundance (n) and dominance (D) using classes according to Losos et al. (1984). Diversity was assessed using the Shannon index $(\mathrm{H})$ based on the natural logarithm, the Berger-Parker index (B) with the proportional dominance of the most abundant species, the Simpson index (d) which differs by its stress (focus) on species diversity of a dataset or the abundance of the most abundant species in the dataset, and finally the equitability index (E) expressing the evenness with which species are distributed (Magurran 2004).

The impact of environmental variables (herb layer character, altitude) on the species structure and distribution of small terrestrial mammal communities and the relation of individual species to these variables were tested by the redundancy analysis (RDA), using Monte Carlo permutation procedure in CANOCO (Ter Braak, Šmilauer 2002; Lepš, Šmilauer 2003) and Spearman's rank correlation coefficient (STATSOFT, Inc. 1999).

\section{Results and Discussion}

A total of 588 small rodents of 10 species (3 insectivorous - Soriciomorpha species and 7 rodent species - Rodentia) were captured in the Jeseníky Mts. in the monitored period. The yellow-necked mouse (Apodemus flavicollis) was the most abundant - ( $\mathrm{n}=177 ; \mathrm{D}=30.1 \%)$, followed by the bank vole (Clethrionomys glareolus) - ( $\mathrm{n}=159$; $27.0 \%$ ) and the field vole (Microtus agrestis) $(\mathrm{n}=144 ; \mathrm{D}=24.5 \%)$, all of them highly eudominant ( $>10 \%)$. Compared to these species, the remaining rodent species were in minority, encompassing the sub-dominant $(\mathrm{D}=2-5 \%)$ common vole ( $M$. arvalis $)-(\mathrm{n}=21 ; \mathrm{D}=3.6 \%)$ and subrecedent $(\mathrm{D}<1 \%)$ wood mouse (A. sylvaticus) $(\mathrm{n}=4 ; \mathrm{D}=0.7 \%)$, the European pine vole (M. subterraneus $)-(\mathrm{n}=2 ; \mathrm{D}=0.3 \%)$ and the hazel dormouse (Muscardinus avellanarius $)-(\mathrm{n}=1 ; \mathrm{D}=0.2 \%)$. The only abundant and eudominant insectivorous species was the common shrew (Sorex araneus) - $(\mathrm{n}=74 ; \mathrm{D}=12.6 \%)$, while the other two species - the pygmy shrew (S. minutus) - ( $\mathrm{n}=1 ; \mathrm{D}=0.2 \%)$ and the lesser white-toothed shrew (Crocidura suaveolens $)$ - $(\mathrm{n}=2 ; \mathrm{D}=0.3 \%)$ were subrecedent. The number of captured individuals and their dominance at individual plots is shown in Tab. 5 and 6.

Tab. 2: Basic geographical characteristics of the experimental plots in the Beskydy Mts.

\begin{tabular}{|c|c|c|c|c|}
\hline Site & GPS & Altitude & FVB & Exposure \\
\hline 1 & 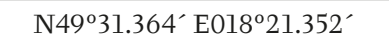 & 650 & 5 & NW \\
\hline 2 & $\mathrm{~N} 49^{\circ} 31.319^{\prime} \mathrm{E} 018^{\circ} 21.341^{\prime}$ & 665 & 5 & NW \\
\hline 3 & $\mathrm{~N} 49^{\circ} 29^{\prime} 44.8^{\prime \prime} \mathrm{E} 018^{\circ} 23^{\prime} 49.6^{\prime \prime}$ & 830 & 5 & 0 \\
\hline 4 & $\mathrm{~N} 49^{\circ} 29^{\prime} 40.6^{\prime \prime} \mathrm{E} 018^{\circ} 23^{\prime} 55.8^{\prime \prime}$ & 815 & 5 & SW \\
\hline 5 & $\mathrm{~N} 49^{\circ} 29^{\prime} 54.1^{\prime \prime} \mathrm{E} 018^{\circ} 21^{\prime} 59.0^{\prime \prime}$ & 1180 & 7 & SE \\
\hline 6 & $\mathrm{~N} 49^{\circ} 29^{\prime} 56.0^{\prime \prime} \mathrm{E} 018^{\circ} 22^{\prime} 02.1^{\prime \prime}$ & 1180 & 7 & SE \\
\hline 7 & $\mathrm{~N} 49^{\circ} 30^{\prime} 38.3^{\prime \prime} \mathrm{E} 018^{\circ} 18^{\prime} 55.7^{\prime \prime}$ & 980 & 6 & $\mathrm{~N}$ \\
\hline 8 & $\mathrm{~N} 49^{\circ} 30^{\prime} 39.0^{\prime \prime} \mathrm{E} 018^{\circ} 18^{\prime} 56.6^{\prime \prime}$ & 980 & 6 & $\mathrm{~N}$ \\
\hline 9 & $\mathrm{~N} 49^{\circ} 30^{\prime} 32.3^{\prime \prime} \mathrm{E} 018^{\circ} 18^{\prime} 54.6^{\prime \prime}$ & 1010 & 6 & SW \\
\hline 10 & $\mathrm{~N} 49^{\circ} 28^{\prime} 36.0^{\prime \prime} \mathrm{E} 018^{\circ} 20^{\prime} 36.4^{\prime \prime}$ & 620 & 5 & SE \\
\hline 11 & $\mathrm{~N} 49^{\circ} 28^{\prime} 38.1^{\prime \prime} \mathrm{E} 018^{\circ} 20^{\prime} 37.5^{\prime \prime}$ & 620 & 5 & ne \\
\hline 12 & $\mathrm{~N} 49^{\circ} 30^{\prime} 44.9^{\prime \prime} \mathrm{E} 018^{\circ} 19^{\prime} 12.7^{\prime \prime}$ & 855 & 6 & $\mathrm{~N}$ \\
\hline 13 & $\mathrm{~N} 49^{\circ} 30^{\prime} 44.9^{\prime \prime} \mathrm{E} 018^{\circ} 19^{\prime} 12.7^{\prime \prime}$ & 855 & 6 & $\mathrm{~N}$ \\
\hline 14 & $\mathrm{~N} 49^{\circ} 29^{\prime} 57.3^{\prime \prime} \mathrm{E} 018^{\circ} 21^{\prime} 41.5^{\prime \prime}$ & 1205 & 7 & SW \\
\hline 15 & $\mathrm{~N} 49^{\circ} 29^{\prime} 55.1^{\prime \prime} \mathrm{E} 018^{\circ} 21^{\prime} 45.5^{\prime \prime}$ & 1195 & 7 & SW \\
\hline 16 & $\mathrm{~N} 49^{\circ} 29^{\prime} 57.9^{\prime \prime} \mathrm{E} 018^{\circ} 21^{\prime} 41.5^{\prime \prime}$ & 1205 & 7 & SW \\
\hline 17 & $\mathrm{~N} 49^{\circ} 30^{\prime} 00.4^{\prime \prime} \mathrm{E} 018^{\circ} 23^{\prime} 42.8^{\prime \prime}$ & 875 & 5 & E \\
\hline 18 & $\mathrm{~N} 49^{\circ} 29^{\prime} 56.1^{\prime \prime} \mathrm{E} 018^{\circ} 21^{\prime} 40.0^{\prime \prime}$ & 1190 & 7 & SW \\
\hline
\end{tabular}

(FVB - Forest vegetation belt) 
Tab. 3: Characteristics of vegetation cover on the Beskydy Mts monitored plots. in 2007-2011. Figures next to individual components of the herbaceous layer represent cover in \%.

\begin{tabular}{|c|c|c|c|c|c|c|c|c|c|}
\hline Site & El cover & $\begin{array}{l}\text { E1 height } \\
(\mathrm{cm})\end{array}$ & Grass & Weed & Dicotyl. & $\begin{array}{c}\text { Calam. } \\
\text { sp. }\end{array}$ & $\begin{array}{c}\text { Avenella } \\
\text { sp. }\end{array}$ & $\begin{array}{c}\text { Rubus } \\
\text { sp. }\end{array}$ & Seedlings \\
\hline 1 & 100 & 120 & 60 & 40 & 0 & 50 & 15 & 40 & beech \\
\hline 2 & 90 & 80 & 70 & 10 & 10 & 10 & 50 & 5 & beech \\
\hline 3 & 100 & 150 & 60 & 40 & 0 & 50 & 10 & 40 & beech \\
\hline 4 & 100 & 150 & 70 & 27 & 3 & 50 & 5 & 20 & beech \\
\hline 5 & 90 & 70 & 35 & 5 & 50 & 20 & 15 & 0 & white fir \\
\hline 6 & 90 & 70 & 35 & 5 & 50 & 20 & 15 & 0 & beech \\
\hline 7 & 100 & 100 & 90 & 10 & 0 & 80 & 10 & 8 & beech \\
\hline 8 & 100 & 100 & 90 & 10 & 0 & 80 & 10 & 8 & beech \\
\hline 9 & 100 & 100 & 88 & 10 & 2 & 60 & 10 & 8 & beech \\
\hline 10 & 90 & 70 & 20 & 5 & 65 & 0 & 20 & 5 & beech \\
\hline 11 & 100 & 50 & 20 & 10 & 70 & 2,5 & 15 & 5 & beech \\
\hline 12 & 100 & 150 & 90 & 7 & 3 & 70 & 15 & 3 & beech \\
\hline 13 & 100 & 150 & 90 & 7 & 3 & 70 & 15 & 3 & beech \\
\hline 14 & 100 & 120 & 75 & 5 & 20 & 40 & 20 & 3 & beech \\
\hline 15 & 90 & 40 & 15 & 0 & 75 & 5 & 10 & 0 & beech \\
\hline 16 & 100 & 120 & 75 & 5 & 20 & 40 & 20 & 3 & sycamore \\
\hline 17 & 95 & 60 & 90 & 5 & 0 & 80 & 3 & 4 & beech \\
\hline 18 & 100 & 40 & 30 & 0 & 70 & 20 & 10 & 0 & white fir \\
\hline
\end{tabular}

(El cover - total cover of the herbaceous layer, El height - height of the herbaceous layer, Grass - total cover of grass, Weed - total cover of weed, Dicotyl. - total cover of dicotyledonous plants, Calam. sp. total cover of Calamogrostis sp., Avenella sp. - total cover of Avenella sp., Rubus sp. - total cover of Rubus sp.)

With respect to the number of occupied plots, the most frequently found species in the Jeseníky Mts. were the bank vole and the field vole, which occurred at 15 of the 18 monitored plots, while the yellow-necked mouse was detected at 14 plots. The abundance of their occurrence may be explained by the habitat preferences of the monitored species, which are closely related to the nature of their prevailing food. Both voles favour habitats with a welldeveloped herbaceous layer which provides the necessary cover and food supply (Heroldová 1992, Suchomel et al. 2009), a requirement which tree plantations fulfil (see Tab. 3 and 4). However, tree plantations represent only a temporary habitat for the yellow-necked mouse due to their limited food supply in the form of tree seeds (Obrtel, Holišová 1974), which tend to be in short supply in plantations. It may therefore be assumed that the yellow-necked mice use tree plantations mainly when migrating to find food and suitable habitats with sufficient supply of fruiting trees, as they are, unlike the voles, highly mobile and capable of overcoming large distances (Flowerdew et al. 1985).
The population abundance of eudominant species fluctuated strongly in time (see Fig. 1, 2 and 3). This is probably due to the strong impact of tree seed production intensity, or the volume of this food supply respectively. During the research, a high beech nut mast was monitored in 2007 and 2009, which was followed by a sharp rise in the numbers of the yellow-necked mouse and the bank vole in the following year. Both species are significant consumers of tree seeds and respond to easier availability of seed by increased abundance (Suchomel and Heroldová 2008). However, the abundance increase comes with a certain delay (sometimes up to a year). It therefore shifts to the year following the strong mast (Flowerdew et al. 1985). Compared to this, the field vole population did not fluctuate so strongly, as this species feeding predominantly on grasses and their seeds is affected by seed mast to a considerably lesser degree (Heroldová 1992).

Out of the determined insectivorous species, only the common shrew showed a relatively high abundance and dominance. Upon meeting its basic habitat requirements, such as humid 
Tab. 4: Characteristics of vegetation cover of the Jeseníky Mts. monitored plots in 2007-2011. Figures next to individual components of the herbaceous layer represent cover in $\%$.

\begin{tabular}{|c|c|c|c|c|c|c|c|c|c|}
\hline Site & El cover & $\begin{array}{l}\text { E1 height } \\
(\mathrm{cm})\end{array}$ & Grass & Weed & Dicotyl. & $\begin{array}{c}\text { Calam. } \\
\text { sp. }\end{array}$ & $\begin{array}{c}\text { Avenella } \\
\text { sp. }\end{array}$ & $\begin{array}{c}\text { Rubus } \\
\text { sp. }\end{array}$ & Seedlings \\
\hline 1 & 95 & 70 & 75 & 0 & 20 & 60 & 25 & 1 & beech \\
\hline 2 & 100 & 60 & 60 & 30 & 10 & 50 & 15 & 25 & beech \\
\hline 3 & 100 & 50 & 50 & 50 & 5 & 40 & 5 & 45 & beech \\
\hline 4 & 70 & 40 & 40 & 5 & 20 & 30 & 5 & 0 & beech \\
\hline 5 & 100 & 60 & 95 & 5 & 5 & 85 & 10 & 1 & beech \\
\hline 6 & 95 & 50 & 85 & 10 & 5 & 65 & 20 & 1 & beech \\
\hline 7 & 95 & 50 & 90 & 0 & 10 & 55 & 35 & 0 & beech \\
\hline 8 & 95 & 55 & 65 & 0 & 40 & 50 & 15 & 0 & beech \\
\hline 9 & 70 & 60 & 35 & 25 & 10 & 30 & 5 & 20 & beech \\
\hline 10 & 95 & 60 & 70 & 5 & 25 & 35 & 40 & 1 & beech \\
\hline 11 & 100 & 80 & 80 & 10 & 10 & 35 & 45 & 10 & beech \\
\hline 12 & 100 & 70 & 85 & 10 & 5 & 45 & 45 & 10 & beech \\
\hline 13 & 100 & 70 & 85 & 10 & 10 & 35 & 50 & 10 & beech \\
\hline 14 & 100 & 70 & 90 & 10 & 5 & 15 & 70 & 15 & beech \\
\hline 15 & 100 & 40 & 70 & 15 & 15 & 5 & 1 & 5 & beech \\
\hline 16 & 95 & 35 & 55 & 15 & 25 & 10 & 10 & 5 & beech \\
\hline 17 & 95 & 40 & 60 & 35 & 1 & 10 & 0 & 1 & beech \\
\hline 18 & 95 & 30 & 10 & 0 & 80 & 5 & 5 & 0 & beech \\
\hline
\end{tabular}

(El cover - total cover of the herbaceous layer, El height - height of the herbaceous layer, Grass - total cover of grass, Weed - total cover of weed, Dicotyl. - total cover of dicotyledonous plants, Calam. sp. total cover of Calamogrostis sp., Avenella sp. - total cover of Avenella sp., Rubus sp. - total cover of Rubus sp.)

sites with a well-developed humus or forest litter layer or a dense herbaceous layer, this species may be abundant both in the forest and non-forest environment (Anděra 2000). Out of the rarely occurring subrecedent species, only the occurrence of the hazel dormouse and the lesser white-toothed shrew was confirmed in the Jeseníky Mts.

The total diversity of the small mammal community inhabiting the tree plantations in the Jeseníky Mts. was $\mathrm{H}=1.53$ for the Shannon index, $\mathrm{d}=0.76$ for the Simpson index and equitability $\mathrm{E}=0.67$. Diversity at individual plots fluctuated strongly (e.g. $\mathrm{H}=0$ - 1.57; see Tab. 5).

In the Beskydy Mts., a total of 577 small terrestrial mammals of 13 species (5 insectivorous and 8 rodent species) were captured. The eudominant rodent species encompassed the yellow-necked mouse ( $\mathrm{n}=250 ; \mathrm{D}=43.33 \%)$, the bank vole ( $\mathrm{n}=124 ; \mathrm{D}=21.49 \%)$ and the field vole $(\mathrm{n}=107 ; \mathrm{D}=18.54 \%)$. The only sub-dominant species was the wood mouse $(\mathrm{n}=16 ; \mathrm{D}=2.77 \%)$, while the common vole $(\mathrm{n}=8 ; \mathrm{D}=1.39 \%)$ and the hazel dormouse $(n=6 ; D=1.04 \%)$ were classified as recedent species ( $D=1-2 \%)$. The remaining two monitored rodent species - the European pine vole $(n=2 ; D=0.35 \%)$ and the striped field mouse $(n=1 ; D=0.17 \%)$ - were sub-recedent. The only eudominant insectivore was the common shrew ( $\mathrm{n}=58 ; \mathrm{D}=10.05 \%)$. The pygmy shrew $(\mathrm{n}=2 ; \mathrm{D}=0.35 \%)$, the Miller's water shrew $(\mathrm{n}=1$; $\mathrm{D}=0.17 \%)$, the Alpine shrew $(\mathrm{n}=1 ; \mathrm{D}=0.17 \%)$ and the European mole $(n=1 ; D=0.17 \%)$ were subrecedent. The number of captured individuals and their dominance at individual plots is shown in Tab. 6.

The yellow-necked mouse and the bank vole were recorded at every of the 18 Beskydy plots, with the field vole and the common shrew were missing at a single one. The abundance of eudominant species in the Beskydy Mts. in individual years fluctuated similarly to that in the Jeseníky Mts. Stronger seed masts, particularly of beech nuts, were recorded in 2007 and 2009. Populations of granivorous species (Clethrionomys glareolus and particularly Apodemus flavicollis) responded to both by an increase in abundance.

The diversity of small mammal community in the Beskydy Mts. according to the Shannon index was $\mathrm{H}=1.52$, according to the Simpson 


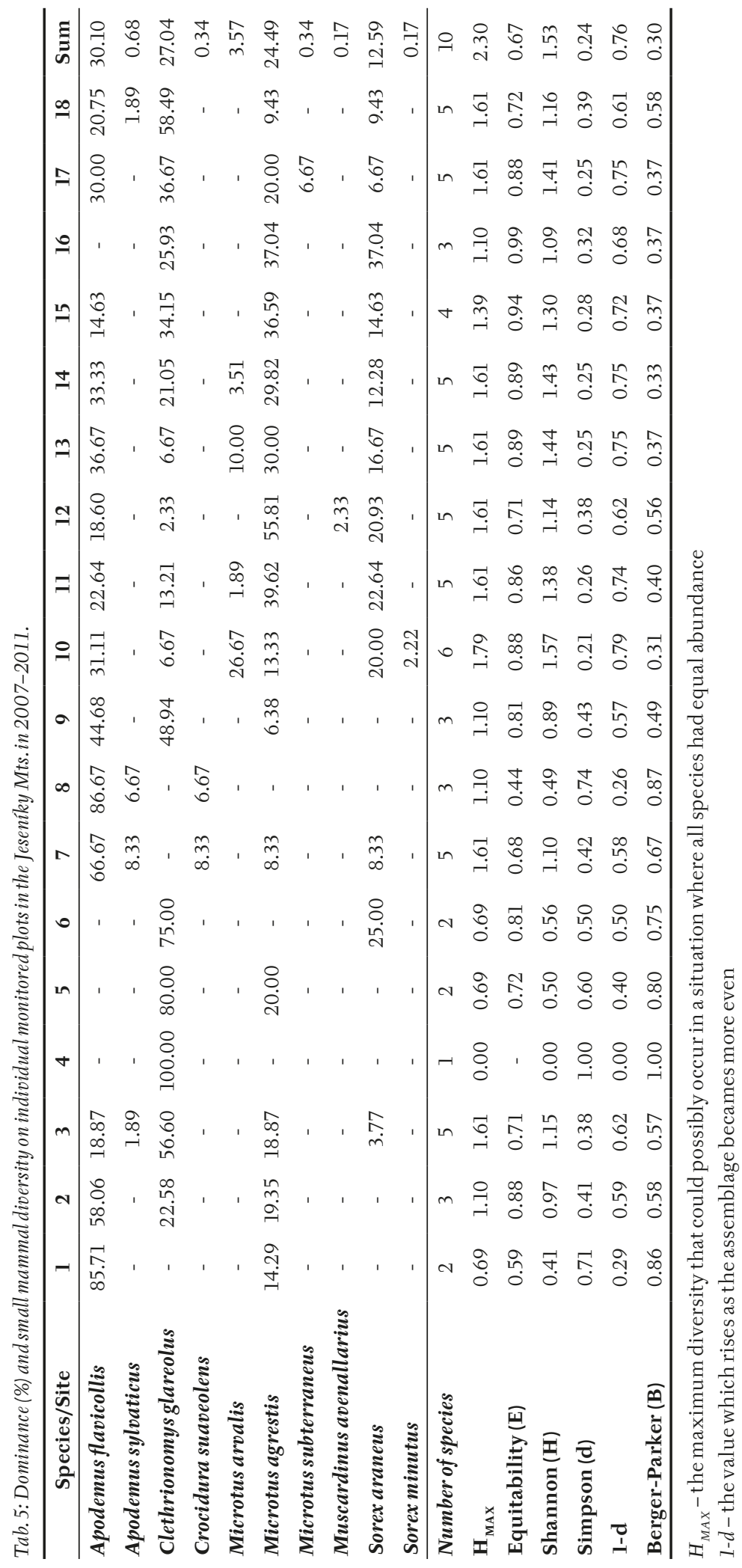




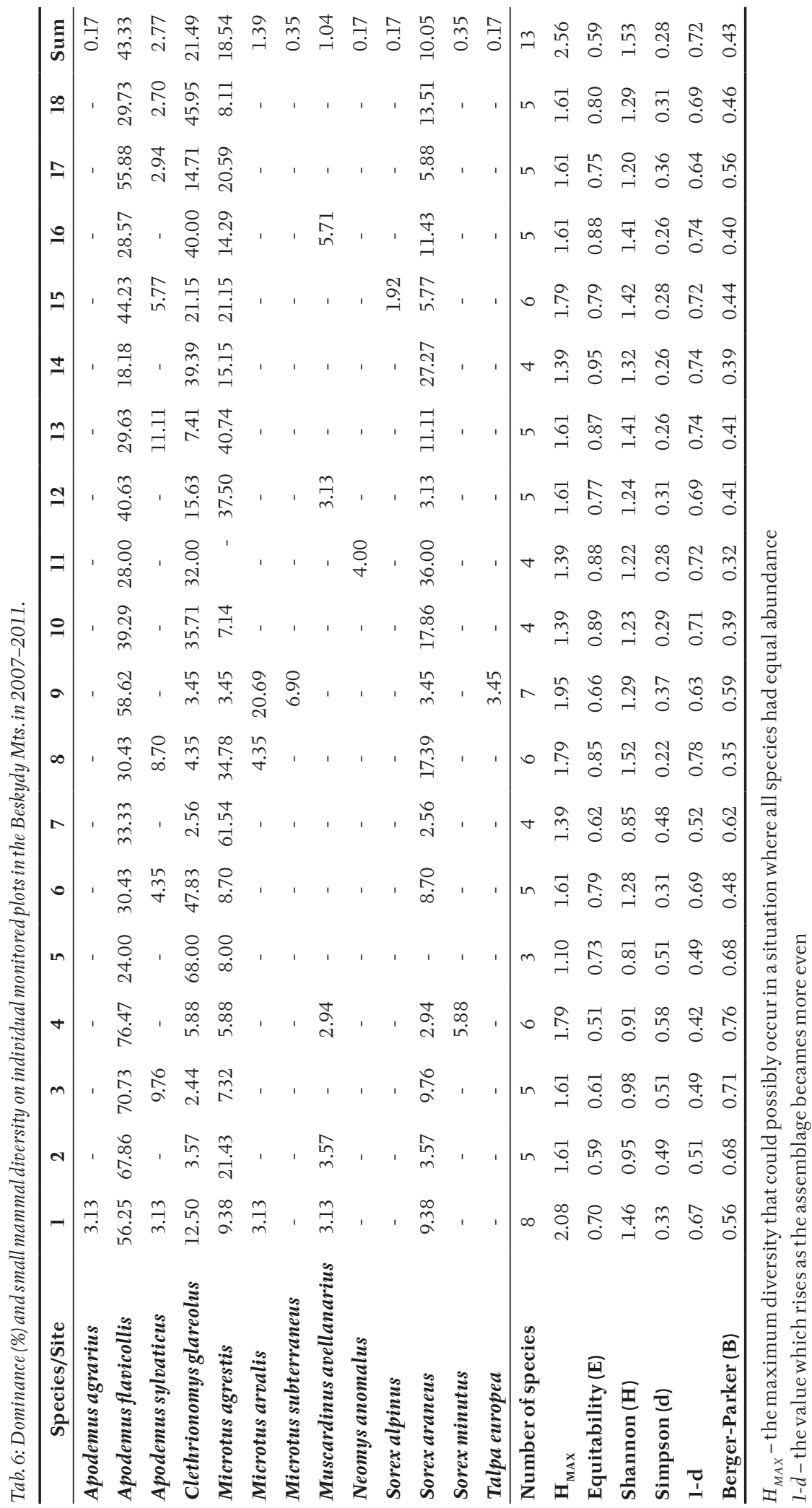




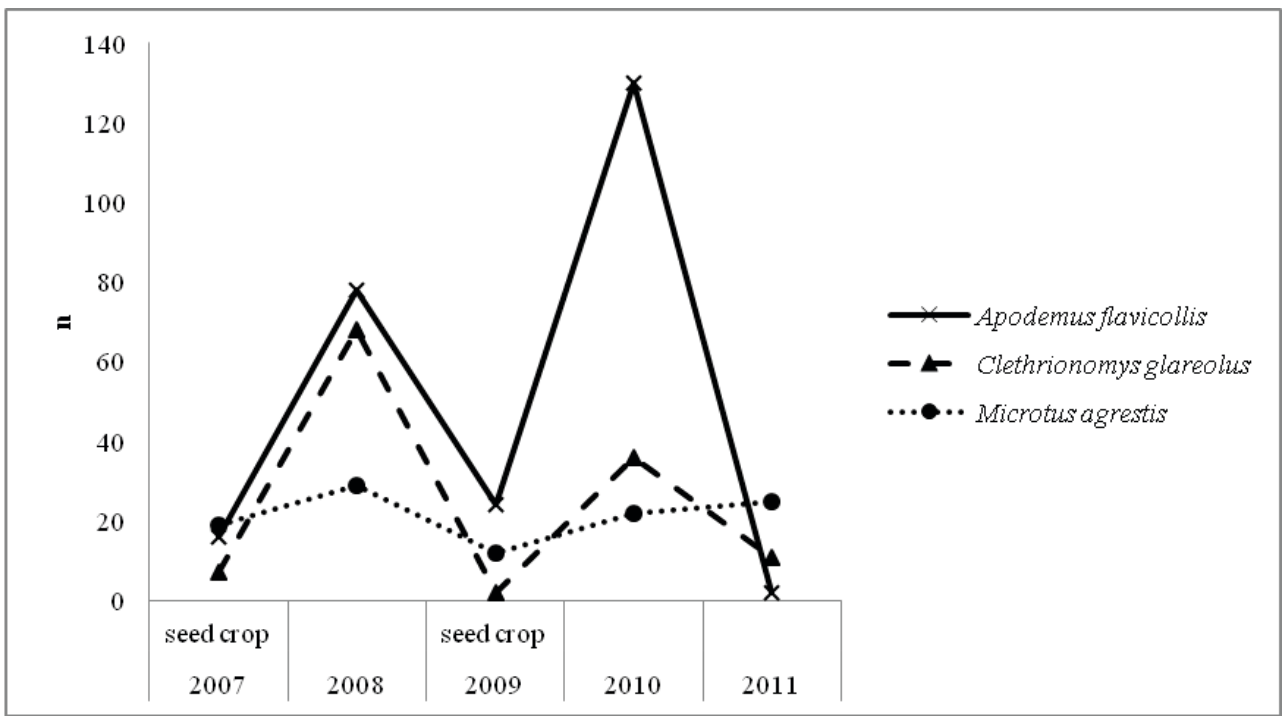

Fig. 1: Oscillation of population dynamics of selected small terrestrial mammal species in the Beskydy Mts. in 2007-2011 on the monitored plantations in relation to beech nut masts in 2007 and 2009. (n-number of specimens).

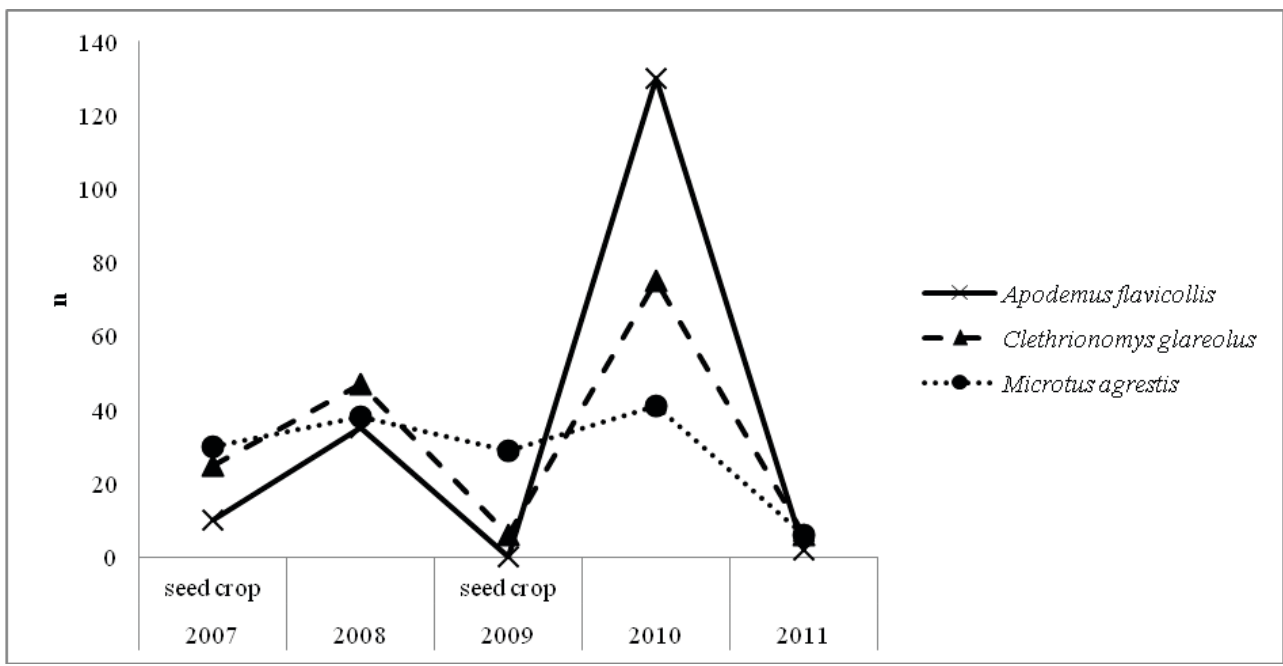

Fig. 2: Oscillation of population dynamics of selected small terrestrial mammal species in the Jeseníky Mts. in 2007-2011 on the monitored plantations in relation to beech nut masts in 2007 and 2009. (n-number of specimens).

index $d=0.722$, equitability was $E=0.595$. The Shannon index at individual plots ranged between $\mathrm{H}=0.81-1.52$, with the Simpson index ranging betweend $=0,42-0,78$ (for details see Tab. 6).

Results of RDA clearly indicate a significant impact (with the exception of stand age) of the habitat character (altitude, herb layer composition) on the structure and distribution of the small terrestrial mammal community (Fig. 4, 5). Microtus arvalis and M. agrestis gave particular preference to habitats with prevailing grasses which condition the occurrence of these vole species with respect to their habitat and food preferences (Heroldová 1992, Heroldová et al. 2007; Suchomel et al. 2009). Clethrionomys glareolus, on the other hand, preferred habitats with dicotyledonous plants, particularly in combination with Rubus sp., it feeds on (Holišová 1971; Hansson 1985).

Tree plantations represent small-scale open habitats in the vicinity of closed stands, which explains the occurrence of both forest and non-forest species of small mammals. Owing 


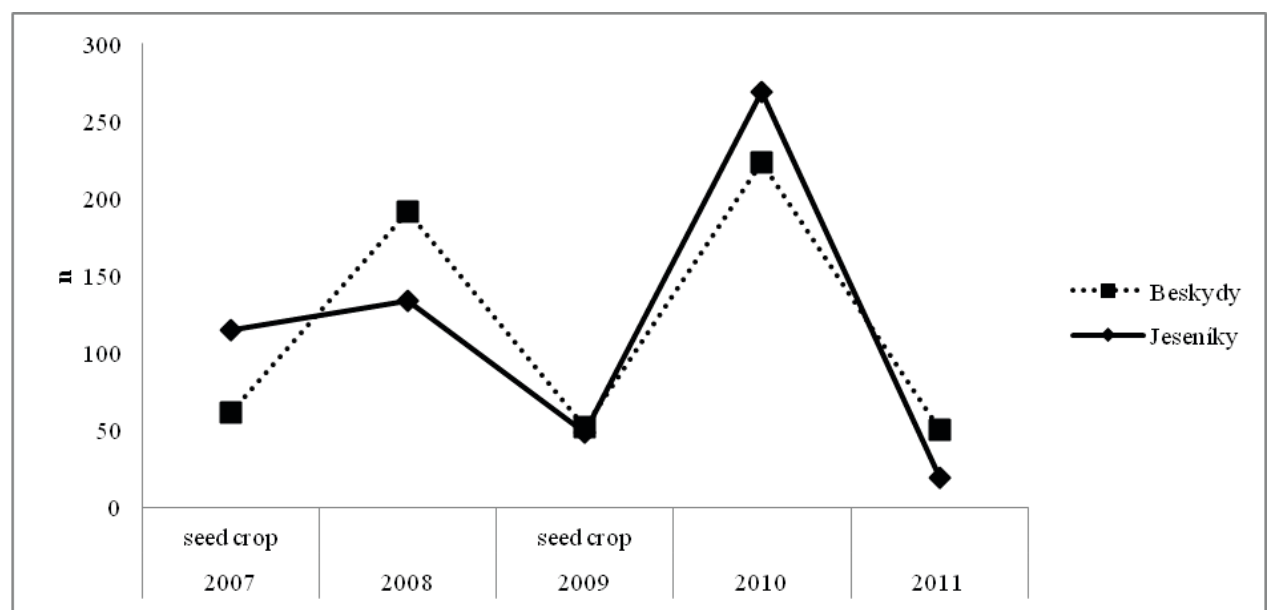

Fig. 3: Comparison of the total number of small terrestrial mammals captured on the monitored plantations in 2007-2011 in relation to beech nut masts in 2007 and 2009. (n- number of specimens).

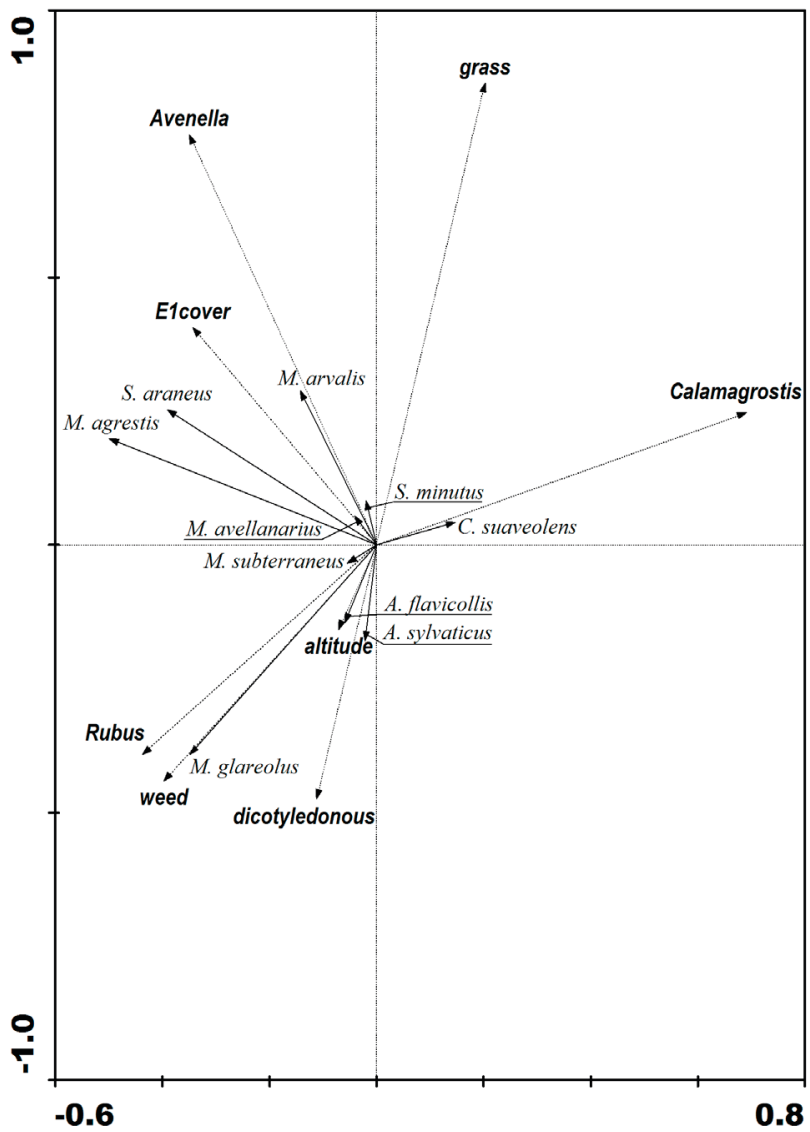

Fig.4: RDA results: diagram showing the relation between environmental variables and small terrestrial mammal communities at plantations in the Jeseniky Mts. in 2007 - 2011. Differences between individual years were statistically significant $(F=6.193 ; p=0.039)$ and as such were included in the analysis as co-variables. This model was highly significant $(F=4.171$, $p<0.001$ ) and explained $14.9 \%$ (axis 1), respectively $24.1 \%$ (axis 2) of species data variability. (E1 cover - total cover of herb layer; grass - cover of grass; Avenella - cover of Avenella sp.; Calamagrostis - cover of Calamgrostis sp.; dicotyledonous cover of dicotyledonous plants; Rubus - cover of Rubus sp.; weed - cover of forest weed). 


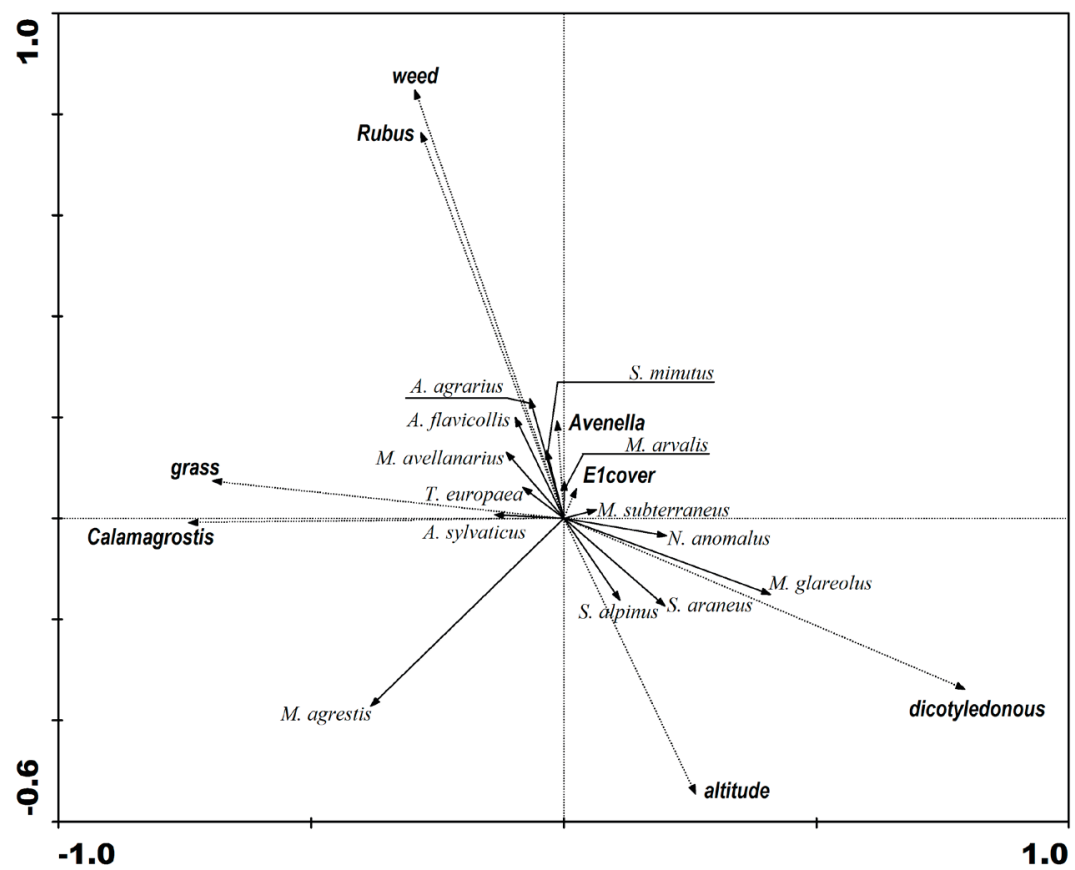

Fig.5: RDA results: diagram showing the relation between environmental variables and small terrestrial mammal communities at plantations in the Beskydy Mts. in 2007 - 2011. Differences between individual years were statistically significant $(F=11.321 ; p<0.001)$ and as such were included in the analysis as co-variables. This model was highly significant $(F=2.990$, $p<0.001$ ) and explained $11.8 \%$ (axis 1), respectively $19.4 \%$ (axis 2) of species data variability. (E1 cover - total cover of herb layer; grass - cover of grass; Avenella - cover of Avenella sp.; Calamagrostis - cover of Calamgrostis sp.; dicotyledonous cover of dicotyledonous plants; Rubus - cover of Rubus sp.; weed - cover of forest weed).

to this, their diversity is comparable with the diversity of ecotone-character habitats or with richly-structured forest stands. Compared with other types of habitats, the the small mammal fauna diversity in the montane plantations of the Jeseníky and Beskydy Mts. may be assessed as relatively rich. For instance, 10 small mammal species were found in the lowland forests of South Moravia (Zejda 1991; Suchomel, Heroldová 2004), 5 (Suchomel et al. 2010) respectively 6 (Zejda 1981) species were determined in the spruce monocultures of the Drahany Uplands, 8 species in the mixed forests of the Oderské Hills (Suchomel, Urban, 2011), 8 species in Šumava (Anděra, Burger 1992) and only 4 species were found in Malá Fatra Mts. (Hlôška, Saniga 2005).

Upon comparison of the species composition of small terrestrial mammal synusia in both mountain ranges, we find that eudominant species in the Jeseníky and Beskydy Mts. are identical. Nevertheless, the representation of individual species was more balanced in the Jeseníky Mts. This means that in rodents the dominance of the yellow-necked mouse over the bank and field voles was not so marked, which reflected in the relatively big difference in equitability of both mountain ranges (Jeseníky E=0.76, Beskydy $E=0.6$ ), despite the fact that the species spectrum in the Beskydy Mts. was wider. Among the less abundant species, the common vole representation was higher in the Jeseníky Mts., while the forest mouse and the hazel dormouse were recorded more frequently in the Beskydy Mts. As for the remaining species, their occurrence is of one-off nature and the collected data can be seen as proof of their occurrence at a given site. A single specimen of the striped field mouse was caught in the Beskydy Mts.

The situation among insectivores in the Beskydy and Jeseníky Mts. is highly similar. The positively most abundant species was the common shrew. Its representation in the Jeseníky Mts. was slightly higher, which may indicate that it found slightly more favourable conditions at the selected plots than in the Beskydy Mts. It has been classified as a eudominant species both in primeval forest reserves $(D=12 \%)$ and on tree plantations ( $D=14-20 \%)$, while in production stands it is considerably rarer $(\mathrm{D}<7 \%)$ (Čepelka 
et al. 2011). This may be related to the management of individual production stands as well as to changes in landscape management as a whole, as known for example from South Moravia (Suchomel, Heroldová 2004). Tree plantations therefore represent an important refuge for the given species. The remaining insectivorous species were recorded only in individual cases and these finds may therefore be seen only as a proof of their occurrence. Apart from the common shrew, the pygmy shrew was monitored in both mountain ranges as well. The remaining insectivorous species were either recorded either only in the Jeseníky Mts. (the lesser whitetoothed shrew) or only in the Beskydy Mts. (the alpine shrew, Miller's water shrew and European mole). A comparison of the collected data indicates that the environment of the Beskydy Mts. has a richer species diversity, despite the fact that a long-term downward trend in their absolute and relative abundance may be traced (Bryja et al. 1999; 200la; Suchomel, Heroldová 2004).

The total diversity of small mammal communities in the Beskydy and Jeseníky Mts. plantations according to the Shannon index does not significantly differ from data from other forest ecosystems, e.g. from plantations in the Keleč Uplands ( $\mathrm{H}=1.456-1.557$; Suchomel, Urban 2011), the isolated forest complexes in South Moravia ( $\mathrm{H}=1.5$; Suchomel, Heroldová 2004) or the primeval forest stands at Kněhyně in the Beskydy Mts. where $\mathrm{H}$ oscillated between 1.27-1.67 (Bryja et al. 2001, Čepelka et al. 2011). These relatively high values become apparent when compared e.g. with beech primeval forest stands at an early stage of disintegration $(\mathrm{H}=1.0$ 1.12, Suchomel, Urban 2011), beech production monocultures ( $\mathrm{H}=0.68-0.9$, Suchomel, Urban 2011), spruce monocultures $(H=1.00$, Suchomel et al. 2010) or even the floodplain forests of South Moravia ( $\mathrm{H}=0.97-1.04$, Zejda 1976).

In the course of our monitoring, both the Shannon and the Simpson indices were slightly higher in the Jeseníky Mts. ( $\mathrm{H}=1,534$; $\mathrm{d}=0.76)$ than in the Beskydy Mts. $(\mathrm{H}=1.526 ; \mathrm{d}=0.72)$. The total number of species in the Beskydy Mts. was higher but the Jeseníky Mts. showed more evenly distributed populations of eudominant species.

\section{Summary}

Owing to their ecotone character, forest tree plantations play a major role in the small terrestrial mammal biodiversity, which becomes apparent particularly upon comparison with closed canopy high forests. The monitored small mammal communities of the forest plantations in the Beskydy and Jeseníky Mts. differed in the higher number of species found in the Beskydy Mts., while a more balanced structure of eudominant species was found in the Jeseníky Mts, which was reflected in higher values of biodiversity indices and particularly in equitability. Both mountain ranges were characteristic of high dominance of three rodent species, the yellow-necked mouse, the bank vole and the field vole (in both regions D>80\%). From the forestry perspective, all these species have a significant impact on both the natural and artificial regeneration of forest trees, whether due to their consumption of seeds or gnawing damage caused to plants and seedlings. This is of a major importance at present, because the monitored regions are subject to transitions from spruce monocultures to forests close to nature with a higher percentage of broadleaved species. Populations of granivorous rodents inhabiting the open habitats of plantations are, similarly to forests, affected by seed masts in the surrounding stands. Seed mast therefore may be used to predict population growths of selected species both in high forests and on tree plantations. Moreover, forest plantations provide an important refuge for populations of the common shrew.

\section{Acknowledgements}

The paper was financially supported by the NAZVQH72075 and MSM6215648902. 


\section{References}

Anděra, M. 2000: Atlas rozšírení savcư v České republice. Předběžná verze. III. Hmyzožravci (Insectivora). [Atlas of the mammals of the Czech republic. A Provisional Version. III. Insectivores (Insectivora)]. Národní muzeum, Praha, 108 s.

AnDĚrA, M. 2011: Current distributional status of rodents in the Czech Republic (Rodentia). Lynx n. s., 42: 5-82.

Anděra, M., Beneš, B. 2001: Atlas rozšírení savců v České republice. Předběžná verze. IV. Hlodavci (Rodentia) - část 1. Krečkovití (Cricetidae), hrabošovití (Arvicolidae), plchovití (Gliridae). [Atlas of the mammals of the Czech republic. A Provisional Version. IV. Rodents (Rodentia) - Part 1. Hamsters (Cricetidae), voles (Arvicolidae), dormice (Gliridae)]. Národní muzeum, Praha, 156 s.

Anděra, M., Beneš, B. 2002: Atlas rozšírení savců v České republice. Předběžná verze. IV. Hlodavci (Rodentia) - část 2. Myšovití (Muridae), myšivkovití (Zapodidae). [Atlas of the mammals of the Czech republic. A Provisional Version. IV. Rodents (Rodentia) - Part 2. Mice and rats (Muridae), jumping mice (Zapodidae)]. Národní muzeum, Praha, $116 \mathrm{~s}$.

Anděra, M., Burger, P. 1992: The community of small terrestrial mammals in a climax spruce forest (the Sumava Mts.). Folia Zoologica, 41 (2): 97-106.

BENEŠ, B. 1974: Sbírka savců Slezského muzea a její vývoj. [Collection of mammals of Silesian Museum and its development]. Časopis Slezského muzea Opava, 23 (suppl.): 66-71.

BENEš, B. 1986: Savci v potravě sýce rousného (Aegolius funereus) z Rejvízu (Jeseníky). [Säugetiere in der Nahrung des Rauhfusskauzes]. Časopis Slezského zemského muzea, série A - vědy přírodní, 35: 219-225.

Bryja, J., Šugerková, M., Heroldová, M. 1999: Drobní zemní savci (Insectivora, Rodentia) nadregionálního biocentra Kněhyně Čertův mlýn (předběžné výsledky). [Small mammal communities (Insectivora, Rodentia) Kněhyně - Čertův mlýn bio-centre (preliminary results)]. Zpravodaj Beskydy, 12: 151-156.

Bryja, J., Heroldová, M., ZejdA, J. 200la: Společenstva drobných savců ve vrcholových partiích Beskyd. [Small mammal communities at the top parts of the Beskids Mts.]. Beskydy, 14: 201-208.

Bryja, J., Heroldová, M., ZejdA, J. 2001b: Drobní zemní savci (Insectivora, Rodentia) vrcholových partií Moravskoslezských Beskyd. [Small mammal communities (Insectivora, Rodentia) of the top parts of the Mora-
vian-Silesian Beskids]. Časopis Slezského zemského muzea, série A - vědy přírodní, 50: 105-112.

Bryja, J., Heroldová, M. And Zejda, J. 2001: Společenstva drobných savců ve vrcholových partiích Beskyd. [Small mammal communities at the top parts of the Beskids Mts.]. Beskydy, 14: 201-208.

ČapeK, M., Heroldová, M., Zejda, J. 1998: Birds and small mammal communities in a clearing caused by air pollution. Folia Zoologica, 47(1): 21-28.

Čepelka, L., Suchomel, J., Purchart, L., HerOLDOVÁ, M. 2011: Small mammal diversity in the Beskydy Mts. forest ecosystems subject to different forms of management. Beskydy: The Beskids bulletin, 4 (2): 101-108.

Flowerdew, S. R., Gurnell, J., Gipps, J. M. W. (eds.) 1985: The ecology of woodland rodents bank voles and wood mice. Symposia of the Zoological Society of London, 55: 89-115.

Hansson, L. 1985: Clethrionomys food: generic, specific and regional characteristics. Annales Zoologici Fennici, 22: 315-318.

Heroldová, M. 1992: The diet of Microtus agrestis in immission clearings in the Krušné hory Mts., Folia Zoologica., 41: 11-18.

Heroldová, M., Zejda, J. 1995: Výsledky výzkumu společenstva drobných zemních savců v oblasti Beskyd s ohledem na poškozování lesních porostů imisemi. [Results of the small mammals communities research in the area of the Beskids in relation to the damage caused by emission to the forest stands]. Zpravodaj Beskydy, 7: 153-156.

Heroldová, M., Suchomel, J., Purchart, L., HoMOLKA, M., KAMler, J. 2007: Small forest rodents - an important factor in the regeneration of forest stands. Beskydy, 20: 217-220.

HLÔŠKa, L., SANIGA, M. 2005: Community structure of small mammals (Insectivora, Rodentia) in the Klačianska Magura National Nature Reserve (Malá Fatra Mts., Slovakia). Folia Oecologica, 32: 59-67.

Holišová, V. 1971: The food of Clethrionomys glareolus at different population densities. Acta Scientiarum Naturalium Academiae Scientiarum Bohemicae Brno (n.s.), 5: 1-43.

Kamler, J., Turek, K., Homolka, M., Bukor, E. 2010: Rodent-caused damage to forest trees from the viewpoint of forestry practice. Journal of Forest Science, 56 (6): 265-270.

Kamler, J., Turek, K., Homolka, M., Bañař, P., Barančeková, M., Heroldová, M., Krojerová, J., Suchomel, J., Purchart, L. 2011: Inventory 
of rodent damage to forests. Journal of Forest Science, 57 (5): 219-225.

KRATOCHVíl, J. 1955: „Velký kotel“ - zoologická zahrada drobných savců v Jesenících. [The "Big kettle" - zoological garden of small mammals in Jeseníky Mts.]. Ochrana prírody, 10 (10): 289-294.

Kratochvíl, J., Grulich, I. 1949: Příspěvek k poznání savčí zvířeny Jeseníků I. [Contribution to the knowledge of mammals of Jeseníky Mts. I.]. Př́rodovédný sborník Ostravského kraje, 10: 177-195.

Kratochvíl, J., Grulich, I. 1950: Příspěvek k poznání ssavčí zvířeny Jeseníků II. [Contribution to the knowledge of mammals of Jeseníky Mts. II.]. Př́rodovédný sborník Ostravského kraje, 1: 202-243.

LePš, J., Šmilauer, P. 2003: Multivariate analysis of ecological data using CANOCO. Cambridge University Press, London, 269 pp.

Losos, B., Gulicka, J., Lellák, J., PeliKÁn, J. 1984: Ekologie živočichü. [Ecology of animals]. SPN, Praha, 316 s.

MagurRan, A. E. 2004: Measuring biological diversity. Blackwell Science, Oxford, 256 pp.

Nevadbová, J., Gaisler, J. 2000: Communities of terrestrial small mammals in two mountain ecosystems influenced by air pollution. Folia Zoologica, 49: 295-304.

OBRtel R., Holišová, V. 1974: Trophic niches of Apodemus flavicollis and Clethrionomys glareolus in a lowland forest. Acta Scientiarum Naturalium Academiae Scientiarum Bohemicae Brno, 8 (7): 1-37.

Remeš, M. 1927: Savci Moravy a Slezska. [Mammals of Moravia and Silesia]. Časopis Vlasteneckého spolku muzejního v Olomouci, 38 (1-4): 32-52.

Statsoft, Inc. 1999: Electronic Statistics Textbook. Tulsa, OK: StatSoft. WEB: http://www. statsoft.com/textbook/stathome.html.

Suchomel, J., Čepelka, L., Purchart, L. 2011: Pilot study of the impact of vole (Arvicolinae) on European beech (Fagus sylvatica) plantations in the Jeseníky Mts. (Czech Republic). Beskydy: The Beskids bulletin, 4 (2): 127-132.

Suchomel, J., Heroldová, M. 2004: Small terrestrial mammals in two types of forest complexes in intensively managed landscape of South Moravia (The Czech Republic). Ekológia (Bratislava), 23 (4): 377-384.

Suchomel, J., Heroldová, M. 2008: Effect of seed crop of trees on the abundance and body parameters of granivorous mammals in isolated forest stands of southern Moravia (The Czech Republic). Polish Journal of Ecology, 56 (1): 155-160.
Suchomel, J., Heroldová, M., Purchart, L. 2007: The study of changes in the synusia of small terrestrial mammals (Insectivora, Rodentia) of top parts of the Beskids (preliminary results). In Kula, E., Tesař, V. Beskydy. 20. vyd., Brno: Mendelova zemědělská a lesnická univerzita $\mathrm{v}$ Brně. Lesnická a dřevařská fakulta, 211-216.

Suchomel, J., Krojerová, J., Heroldová, M., Purchart, L., Barančeková, M., Homolka M. 2009: Habitat preferences of small terrestrial mammals in the mountain forest clearings. Beskydy: The Beskids bulletin, 2 (2): 195-200.

Suchomel, J., Purchart, L., Urban, J. 2010: Spruce monocultures of the Drahanská vrchovina Upland (Czech Republic) as the biotope of small terrestrial mammals (Rodentia, Soricomorpha). Acta Universitatis agriculturae et silviculturae Mendelianae Brunensis, 53 (2): 185-193.

Suchomel, J., Urban, J. 2011: Small mammals of a forest reserve and adjacent stands of the Kelečská pahorkatina Upland (Czech Republic) and their effect on the forest dynamics. Journal of Forest Science, 57 (2): 50-58.

Ter Braak C. J. F., Šmilauer P. 2002: CANOCO Reference Manual and CanoDraw for Windows User's Guide: Software for Canonical Community Ordination (version 4.5).

Zapletal, M. 1957: Příspěvek k poznání roztočů drobných savců „Velkého kotle“ a jeho blízkého okolí v Jesenících. [Contribution to the knowledge of mites of small mammals of "Big kettle" and its vicinity in Jeseníky Mts.]. Př́rodovědecký sborník Ostravského kraje, 18: 422-426.

ZEJDA, J. 1976: The small mammal community of a lowland forest. Acta Scientiarum Naturalium Academiae Scientiarum Bohemicae Brno, 10 (10): 1-39.

ZEJDA, J. 1981: The small mammal community of a spruce monoculture. Acta Scientiarum Naturalium Academiae Scientiarum Bohemicae Brno, 15: 1-31.

ZEJDA, J. 1991: A community of small terrestrial mammals. In Penka, M. et al.: Floodplain forest ecosystem II. After Water Management Measures. Academia, Praha, 505-521. 